2015

\title{
Crevice Interments Deconstructed
}

Stephen L. Black

Department of Anthropology, Texas State University

M. Katherine Spradley

Department of Anthropology, Texas State University

Michelle D. Hamilton

Department of Anthropology, Texas State University

Follow this and additional works at: https://scholarworks.sfasu.edu/ita

Part of the American Material Culture Commons, Archaeological Anthropology Commons, Environmental Studies Commons, Other American Studies Commons, Other Arts and Humanities Commons, Other History of Art, Architecture, and Archaeology Commons, and the United States History Commons

Tell us how this article helped you.

This Article is brought to you for free and open access by the Center for Regional Heritage Research at SFA ScholarWorks. It has been accepted for inclusion in Index of Texas Archaeology: Open Access Gray Literature from the Lone Star State by an authorized editor of SFA ScholarWorks. For more information, please contact cdsscholarworks@sfasu.edu. 


\section{Crevice Interments Deconstructed}

\section{Licensing Statement}

Reproduction, posting, transmission, or other distribution or use of the Journal volume, individual article or any portion of the material therein, in any medium, is permitted strictly for personal, non-commercial purposes via a personal-use exemption under a Creative Commons license granted by JTAH.org, Inc. This license exemption requires, as a condition of its granted permission, proper credit be attributed to JTAH.org as copyright holder (e.g., Journal of Texas Archeology and History.org @ 2015). No part of this publication may be reproduced, posted, transmitted, or otherwise utilized or distributed in any form by any means or method for commercial purposes without the express written consent of the Publisher.

Inquiries should be addressed to JTAH Publisher, Suite 307, Box 361, 5114 Balcones Woods Drive, Austin, Texas, 78759.

The Journal of Texas Archeology and History.org is an organization dedicated to furthering research, education and public outreach in the fields of archeology and history concerning Texas and its bordering states of Louisiana, Arkansas, Oklahoma, New Mexico and Northern Mexico; a region we call the "Texas Borderlands." The J.T.A.H. is collaborating with the Index of Texas Archaeology and S.F.A.S.U. to distribute their publication library to the general public via free and open-access channels. Visit www.JTAH.org to submit an article. 


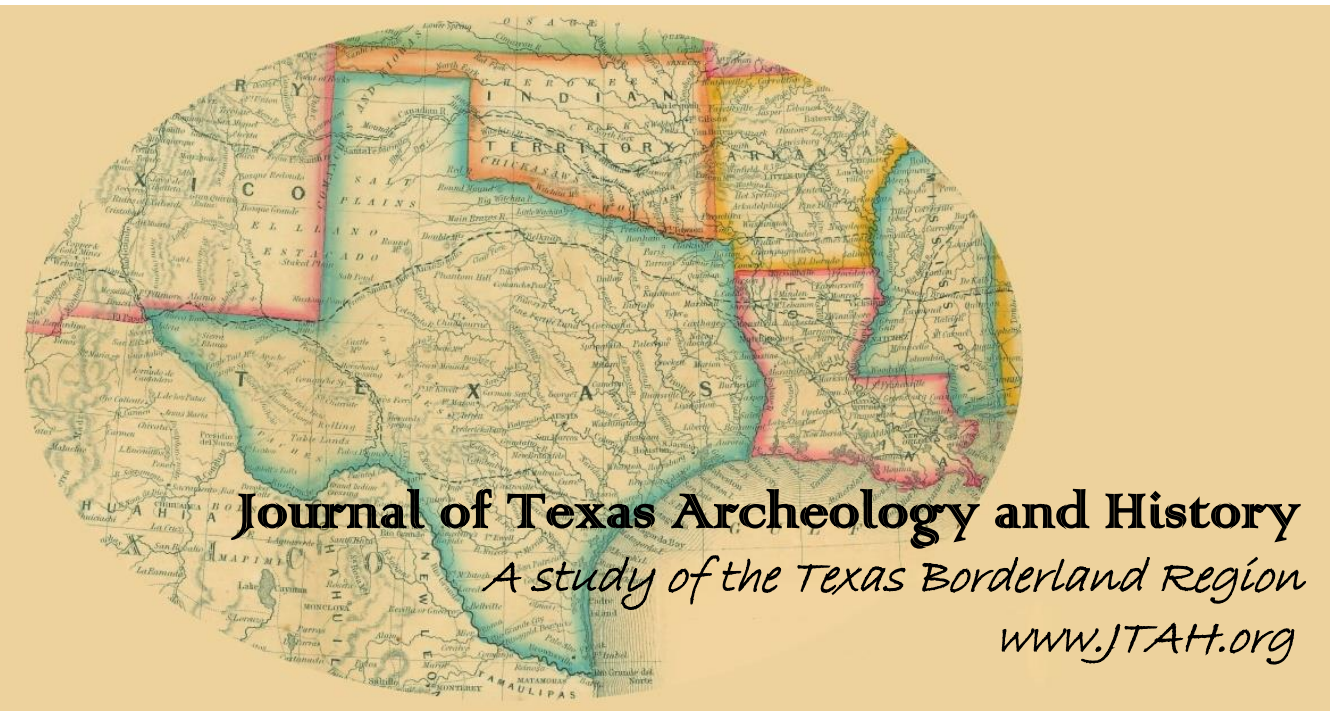

\title{
Article Title: CREVICE INTERMENTS DECONSTRUCTED
}

\author{
Author(s): $\quad$ Stephen L. Black, M. Katherine Spradley, and Michelle D. Hamilton
}

Original Source: J.T.A.H. Volume 2 (2015), Article 1, pp. 1-16; online 04 January 2015

Recommended Citation: Black, Stephen L., M. Katherine Spradley, and Michelle D. Hamilton; "Crevice Interments Deconstructed", (2015), Journal of Texas Archeology and History Volume 2 (2015), pp. 1-16.

Copyright $(2015$ by Journal of Texas Archeology and History.org, Inc. All rights reserved. Online/Digital publication: ISSN 2334-1874

The online, digital and print versions of the publication "Journal of Texas Archeology and History" are published by Journal of Texas Archeology and History.org, Inc., a Texas nonprofit IRC Section 501(c)(3) corporation.

Reproduction, posting, transmission, or other distribution or use of the Journal volume, individual article or any portion of the material therein, in any medium, is permitted strictly for personal, non-commercial purposes via a personal-use exemption under a Creative Commons license granted by JTAH.org, Inc. This license exemption requires, as a condition of its granted permission, proper credit be attributed to JTAH.org as copyright holder (e.g. Journal of Texas Archeology and History.org (C) 2015). No part of this publication may be reproduced, posted, transmitted, or otherwise utilized or distributed in any form by any means or method for commercial purposes without the express written consent of the Publisher. Inquiries should be addressed to JTAH Publisher, Suite 307, Box 361, 5114 Balcones Woods Drive, Austin, Texas, 78759.

The Journal of Texas Archeology and History.org is an organization dedicated to furthering research, education and public outreach in the fields of archeology and history concerning Texas and its bordering states of Louisiana, Arkansas, Oklahoma, New Mexico and Northern Mexico; a region we call the "Texas Borderlands." The J.T.A.H. is collaborating with the Index of Texas Archaeology and S.F.A.S.U. to distribute their publication library to the general public via free and open-access channels. Visit www.JTAH.org to submit an article. 


\title{
CREVICE INTERMENTS DECONSTRUCTED
}

\author{
Stephen L. Black, M. Katherine Spradley, and Michelle D. Hamilton
}

\begin{abstract}
The discovery of two well-preserved human crania in a crevice overlooking a springfed creek near Austin, Texas, led to medico-legal, archeological, and bioanthropological investigations aimed at understanding the context and biological affinity of the crania. Archeological excavations uncovered no evidence that the crania were interred in the crevice during prehistoric times. Skeletal analysis showed they were of Native American ancestry. Radiocarbon dating indicated they are contemporary to one another and probably date to the seventh or eighth century A.D. Measured stable isotopic rations of carbon $\left({ }^{13} \mathrm{C} /{ }^{12} \mathrm{C}\right)$ and nitrogen $\left({ }^{15} \mathrm{~N} /{ }^{14} \mathrm{~N}\right)$ derived from human bone collagen samples from the crania are not consistent with other burial populations from the region, having higher nitrogen values than all other comparative samples. The crania also showed polish from repeated handling and several of the molars in one cranium had been glued in place. Taken together, these lines of evidence suggest the crania were removed from an unknown locality outside the Central Texas region, kept in a private collection, and placed in the crevice recently.
\end{abstract}

\section{CREVICE INTERMENTS DECONSTRUCTED}

The discovery of two well-preserved human crania in a narrow limestone crevice overlooking a springfed creek in western Travis County, Texas, led to medico-legal, archeological, and bioanthropological investigations aimed at assessing the contextual and biological affinity of the crania. While it was soon realized that the crania were not of modern age and thus of no interest to criminal investigators, from an archeological perspective their appearance in an open crevice with minimal protection from the elements was unexpected. Were these aboriginal interments? If so, the crania had the potential to add considerably to knowledge of the hunter-gatherer population of the region, provided they had been placed in the crevice in aboriginal times. This article describes how the significance, context, and cultural affiliation of the crania were assessed using a multidisciplinary approach.

\section{SITE SETTING AND BACKGROUND}

The crevice where the crania were found lies within the Balcones Canyonlands along the eastern flank of the Edwards Plateau in Central Texas (Figure 1). In this area the limestone plateau is deeply dissected by steep-sided winding canyons prone to flash flooding, a major reason why the Colorado River was dammed in the 1940s to form the chain of reservoirs known as the Highland Lakes. The site of discovery overlooks a

\footnotetext{
JOURNAL OF TEXAS ARCHEOLOGY AND HISTORY

VOLUME 2:1-16

THE ONLINE PUBLICATION JOURNAL OF TEXAS ARCHEOLOGY AND HISTORY (ISSN 2334-1874)

IS PUBLISHED BY JOURNAL OF TEXAS ARCHEOLOGY AND HISTORY.ORG. COPYRIGHT (C) 2015 JOURNAL OF TEXAS ARCHEOLOGY AND HistORY.ORG. ALL RIGHTS RESERVED.
} 


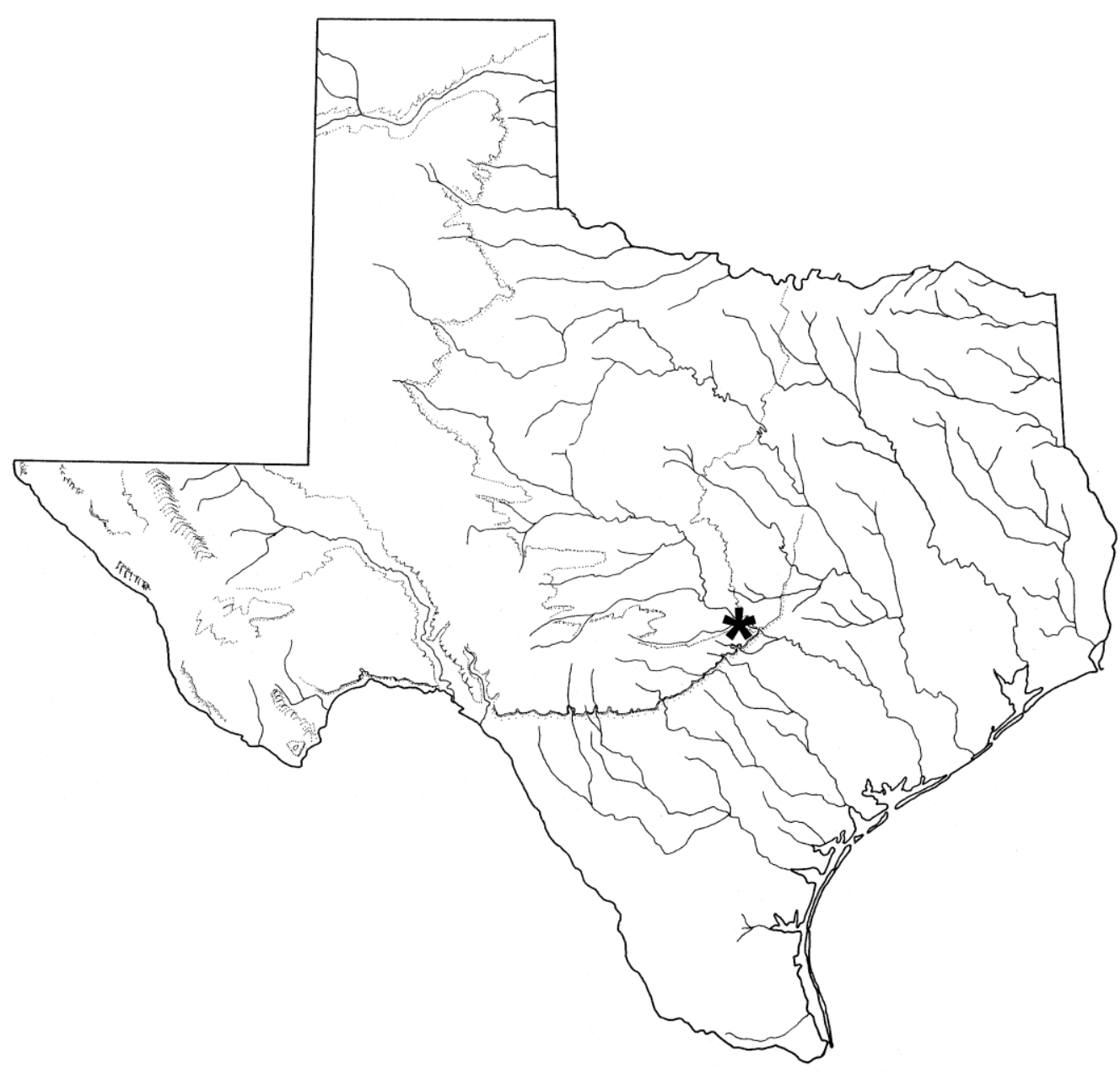

Figure 1. Location of the crania locality in Texas.

spring-fed creek that empties into the Pedernales River, a tributary of the Colorado River. The creek flows year-round as the result of natural springs upstream where permanent natural pools support stands of bald cypress, forming something of a deeply shaded oasis within the relatively dry, juniper-dominated limestone uplands.

The site lies within the Central Texas archeological region, which has an abundant and lengthy prehistoric record of hunter-gatherer life spanning over 13,000 years (Black 1989; Collins 2004; Prewitt 1985). In contrast to the adjacent Blackland Prairie and Texas Coastal Plains to the east and southeast, the Edwards Plateau lacks large cemeteries in open settings, although small numbers of burials are known from open campsites (Steele et al. 1999). Instead, most known prehistoric burials across the Plateau occur in sinkholes, rockshelters, and, occasionally, in crevices. Given the ample evidence of sustained human occupation in the region, it appears that the natural sinkholes that abound across the karstic limestone expanse of the Plateau were used as cemeteries (Bement 1994:133-135; Perttula 2001:34-41). Although multiple human remains have been recovered from several sinkholes, most of these locales have notoriously poor bone preservation 
conditions (e.g., Alvarez 2005; Givens 1968). The Plateau's most thoroughly investigated sinkhole cemetery is the Bering Sinkhole site near Kerrville, Texas (Bement 1994). There the bodies seem to have been interred whole as evidenced by the recovery of both cranial and postcranial bones.

To the northeast of the Edwards Plateau along the Leon River and other Brazos River tributaries in western Bell County sizable rockshelters containing prehistoric cemeteries with dozens of graves are known to have existed (Russell 1936). Most appear to have been looted in the 1920s and 1930s with little or no archeological documentation. The Aycock site (also known as Kell Branch Shelter 1) is a partial exception. This large rockshelter along the Leon River contained a cemetery with at least 32 burials, including three "head burials" (Watt 1936). Two of these consisted of crania interred while still attached to several upper vertebrae, while the third (Burial 4) was characterized as "head only." These crania were found amid extended and flexed skeletons. Watt describes poorly controlled excavations and it is not at all clear that the crania were originally interred separately from postcranial elements or merely appeared that way when hastily exposed by untrained excavators.

In the vicinity of the two isolated crania interments reported in this article, dozens of prehistoric archeological sites have been recorded within a $15 \mathrm{~km}$ radius of the discovery locale, including small rockshelters on the canyon walls, open campsites on the terraces of the Pedernales and Colorado rivers, plant baking facilities known as burned rock middens, chert outcrops where flint was obtained for making stone tools, and various other sites that are collectively typical of the regional archeological record. Most of the known sites in the local area are along the Colorado River within Lake Travis. A modest amount of archeological research was done in the upper reservoir prior to the impoundment of Lake Travis in 1942, including the excavation of the Grelle site, a deep campsite that contained several human interments (Kelley 1941).

A recent article reporting an isolated interment exposed on the shore of Lake Travis summarizes the known burial sites from the Colorado River basin upstream from Austin (Malof and Taylor 2011:254-259). Of these, only a single burial was documented within a rockshelter in Burnet County on Lake Buchanan (Field 1956), and it was purposefully covered with limestone slabs like certain other documented interments along the Colorado River. Nearby the Burnet County rockshelter, along the same sandstone bluff, was a "disarticulated crevice burial. Only the arm and leg were in place, and there was no trace of the skull or teeth" (Field 1956:172). However, Field went on to note that the "site flooded at high water periods," suggesting the crevice interment may have been partially washed away.

\section{DISCOVERY}

A hiker peered into a limestone crevice on the lower wall of a winding canyon and spotted an essentially intact human cranium on the floor of the crevice amid oak leaves and tree roots. The landowner contacted the Travis County Sheriff's Office and a deputy soon arrived, who confirmed it was human and gingerly removed the cranium from the tight quarters, whereupon a second cranium was found directly behind the first. Several detectives and an investigator from the Travis County Medical Examiner's Office examined the immediate vicinity and found no other human remains or associated material. Both crania were taken to the Medical Examiner's Office for evaluation of possible legal and forensic significance. The subsequent Medical 
Examiner's report indicated that the two isolated crania were too old to be of forensic significance and likely represented two adult individuals of Native American ancestry. However, the medico-legal report did not address any contextual issues surrounding the crania. The skulls were returned to the landowner, who then contacted the Texas Historical Commission (THC) to determine if he had a Native American burial locale on his property.

THC archeologist Daniel R. Potter visited the find locale and briefly examined the crania. Potter realized that the finding of two well-preserved crania in a crevice that was relatively open-to-the-elements was somewhat suspect. Nonetheless, he could not rule out the possibility that the crevice had been the original interment location and that additional bones or associated grave inclusions might be present. Potter examined the crevice and the surface of the area around and above the crevice and found no artifacts or other indications of prehistoric occupation. Potter recommended that the landowner seek additional evaluation.

\section{ARCHEOLOGICAL INVESTIGATIONS}

In May and June of 2009 we investigated the locale at the request of the landowner. Based on the initial archeological reconnaissance, two competing explanatory hypotheses were considered: Hypothesis A, the crania were originally deposited in situ in the crevice in prehistoric times (i.e., over 500 years ago) as part of purposeful, primary interments; or Hypothesis B, the crania were deposited secondarily in the crevice in recent times, perhaps by looters who had removed the crania from another, better-protected site. If Hypothesis A was valid, one would expect to find additional bones, assuming the crania had accompanied bodies, and perhaps grave offerings or associated artifacts such as projectile points. Although there are other alternatives (e.g., Hypothesis C, the crania were deposited secondarily in prehistoric times), it seems unlikely that the crania could have been present in the crevice for long without leaving other traces such as fragments of human bone. It was noted that a number of maxillary teeth were missing from both crania postmortem, suggesting that the missing teeth might still be present in the vicinity.

After photographically documenting the crevice and vicinity (Figure 2a-d), the brush overhanging the crevice was cleared and careful examination began. The locale consists of a narrow crevice and an adjacent low overhang at the base of a low, north-facing limestone valley wall. The walls of the crevice and the roof of the overhang are massive limestone blocks that have partially separated from the bedrock through geological processes. The crevice is little more than $50 \mathrm{~cm}$ wide at its mouth (opening), narrowing to less than $30 \mathrm{~cm}$ wide where the crevice terminated, approximately $3 \mathrm{~m}$ into the bluff. The crevice is partially filled with boulder-sized angular bedrock fragments, smaller limestone rocks, leaf litter, silt, and roots. The jumbled infilled materials appear to have accumulated naturally, rather than having been purposefully added. The adjacent low overhang extends approximately $2.5 \mathrm{~m}$ into the bluff along the crevice and gradually angles outward. At the mouth of the overhang its ceiling is about $70 \mathrm{~cm}$ above the bedrock floor, the maximum amount of clearance in the entire overhang. As one stoops and enters the overhang, the roof slopes steeply downward to the rear of the overhang. While native peoples in the region often made use of natural rockshelters, this particular overhang has little or no useful floor space. 


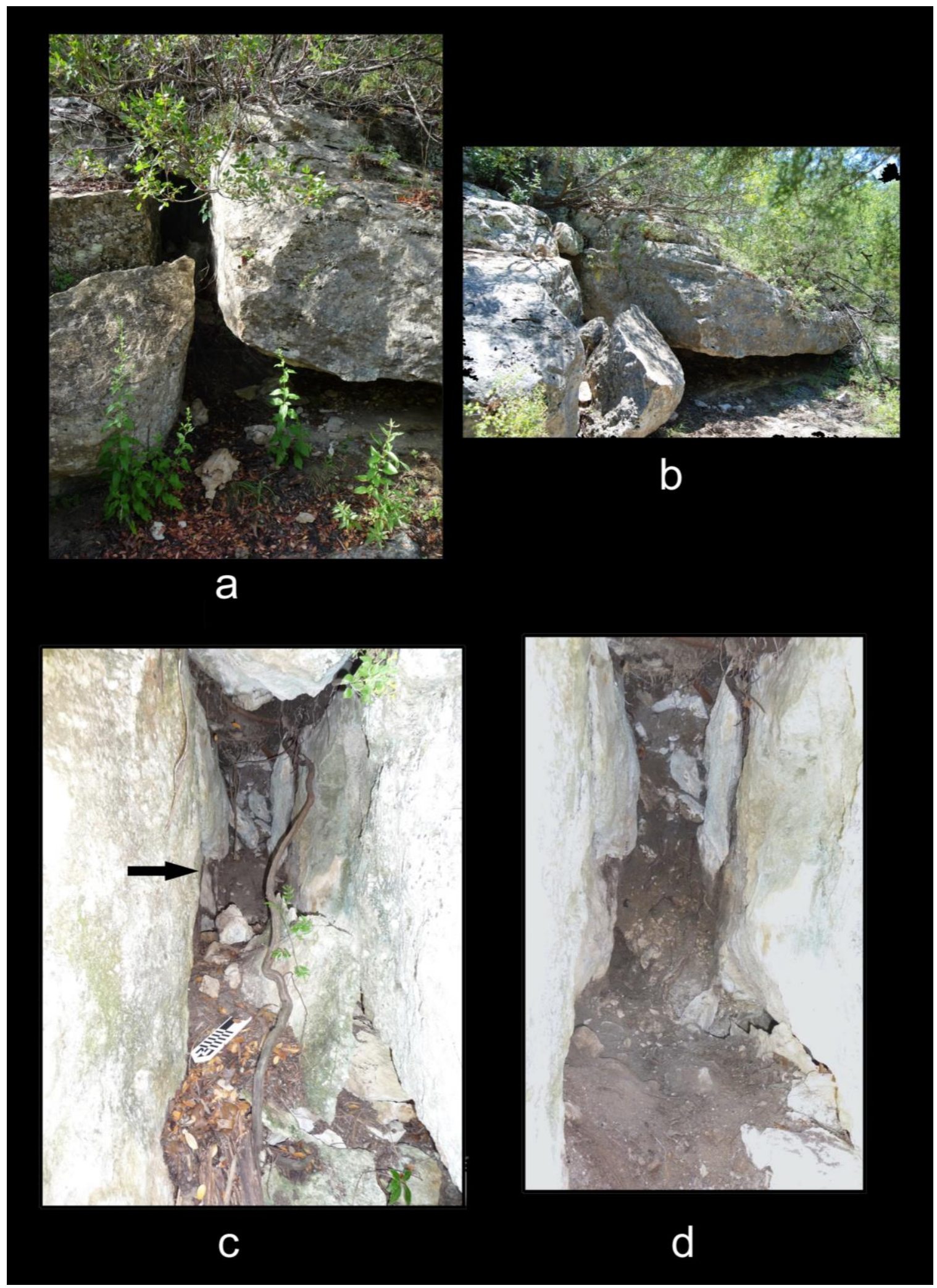

Figure 2. Find locality: $a$, front view of crevice; $b$, side view of crevice showing the low overhang; $c$, interior of crevice before archeological excavation (arrow points to approximate spot where crania had been removed); and d, interior of crevice after excavation. 
The mouth of the crevice and overhang is about $5 \mathrm{~m}$ from the edge of the nearby spring-fed creek, which is normally less than $15 \mathrm{~cm}$ deep at this point. The floor of the outside edge of the overhang is less than $50 \mathrm{~cm}$ above the normal pool elevation of the creek. The crania were resting about $1 \mathrm{~m}$ above the surface of the creek. Although the creek has a relatively small drainage basin, the crevice and overhang are well below highwater flood levels in recent decades, and likely for millennia. Within the overhang, two rounded "columns" of unconsolidated but compact, silty, poorly-sorted sediment extend from the bedrock floor to the ceiling of the overhang. These remnants show that the overhang was once filled with sediment, and that most of the original fill had been scoured out by floodwaters. Given the unconsolidated appearance of the sediment columns, the "original" fill is likely of relatively young age, no more than a few thousand years at most. Indeed, it is reasonable to speculate that the overhang and the adjacent crevice would have experienced multiple cycles of fill and erosion during the Holocene.

The field investigation was done with the working assumption that the crevice had been a primary burial site. Both the crevice (see Figure 2a) and the adjacent overhang area (see Figure 2b), where 10-15 cm or so of sediment covered most of the bedrock floor, were carefully searched. The overhang floor deposit consisted of fairly loose, unconsolidated silt containing gravel-sized angular limestone spalls that graded into dust-sized particles intermixed with leaf litter. The sediment was excavated from an expedient "trench" $40-50 \mathrm{~cm}$ wide and 10-15 cm deep that roughly paralleled the crevice such that it encompassed the material directly down slope from where the crania had been found. It was reasoned that if skeletal materials had been housed in the crevice for any considerable length of time, skeletal fragments would have likely washed down slope from the crevice as colluvial deposits. The excavated sediment was screened through $1 / 4-$ and $1 / 8^{\text {th }}$-inch mesh and carefully search for fragments of bone, teeth, and artifacts. None were found.

Within the crevice the loose limestone rocks, leaf litter, and tree and vine roots were carefully removed in the immediate area where the crania were found as well as deeper within the crevice (see Figure 2c). Finding no trace of bone or a purposeful grave, hand excavations continued into the relatively compact, finer-grained fill directly beneath where the crania had been located. The sediment was screened and searched for fragmentary skeletal and artifactual material with the same result: none was found. The fine matrix was a gray silt containing unsorted decomposed limestone fragments and pebbles, none of them noticeably rounded by stream abrasion. Because the crania had rested against the "back wall" of the compact crevice fill, the fill was cut back approximately $20-30 \mathrm{~cm}$ farther to search for any sign of additional remains (see Figure $2 \mathrm{~d}$ ). Once again, none were found.

In summary, the archeological investigation of the crevice and overhang revealed no evidence that the crania had originally been interred there, with or without other skeletal elements. The lack of additional skeletal fragments fails to support Hypotheses A or C. This leaves Hypothesis B as the best explanation to account for the finding of two crania. In other words, it is highly likely that the crania were deposited in the crevice relatively recently, probably within a decade of being discovered. Otherwise, the bones would have quickly deteriorated given the clear evidence that the crevice was exposed to moisture, roots, rodents, insects, and slope wash from the hillside above the crevice, as well as periodic inundation from creek flooding. The preservation conditions are judged to be very poor as the crevice would have alternated between dry and wet conditions depending on the weather, the alternating cycles being deleterious to skeletal preservation. 


\section{SKELETAL ANALYSES}

\section{Condition of Remains}

Both isolated crania were originally given Medical Examiner case numbers; however, they will be referred to here as $\mathrm{C} 1$ (Cranium 1) and C2 (Cranium 2). Based on the overall color and texture of the bone and the overall biological morphology, both crania are archeological in nature and not of forensic significance.

The preservation of $\mathrm{Cl}$ is excellent (Figures 3 and 4). The entire cranium is complete with only a portion of the left mastoid process broken postmortem, as indicated by the light (fresh) color of the fracture in comparison to the rest of the cranium. The cranium exhibits differential staining with colors of light brown to dark brown to black. The majority of the cranium is light brown with dark brown coloring on the superior and inferior portions of the vault. The cranium has some weathering indicative of water damage on the left fronto-parietal region of the coronal suture. A light coating of soil is evident in the orbital sockets as well as the nasal aperture. The frontal bone and parietal bones possess a shine on the surface of the bone, a typical finding when bone has been continuously handled or touched as trophy or display objects (Haglund and Sorg 1997). Roots are also present in the orbital area suggesting the cranium has been in contact with an earthen surface.

The preservation of $\mathrm{C} 2$ is also excellent (Figures 5 and 6 ) with the exception of the postmortem fractures at the cranial base. Additional postmortem damage is seen on the cranium in the eye orbits and the anterosuperior portion of the maxilla above and around the zygomaticofacial foramen and the left mastoid process. In addition, the left zygomatic arch is almost completely broken off and the occipital bone, at the base of the cranium, is completely broken off. Rodent gnawing is evident on the occipital bone around the posterior portion of the fracture margin. The cranium is stained a light to dark gray and has soil and roots in the cranial vault suggestive of contact with an earthen surface. Additionally, close inspection of this cranium revealed the presence of adhesive material (presumably glue) securing several teeth into their alveolar sockets, strongly suggesting a secondary deposition by an unknown modern individual.

\section{Sex and Age}

Sex and age were assessed following standard methodology outlined in Buikstra and Ubelaker (1994). Following methods outlined by Ascadi and Nemeskeri (1970), both crania exhibit features suggestive of males. These features include projecting nuchal crests, rounded supraorbital margins, and large supraorbital ridges. Although sex estimation is considered population specific, Walker (2008) found the Ascadi and Nemeskeri method suitable for Native Americans.

Age was estimated based on degree of cranial suture closure following the methods of Meindl and Lovejoy (1985) and further refined based on observations of dental loss and attrition. Based solely on cranial sutures, age is estimated between 28 to 56 years for $\mathrm{C} 1$. However, based on the antemortem tooth loss of this individual, the age is most likely 50+ years of age at death. Age is estimated between 31 to 61 years for C2, although a more likely age is between $30-40$ years based on the dental attrition of this individual. 


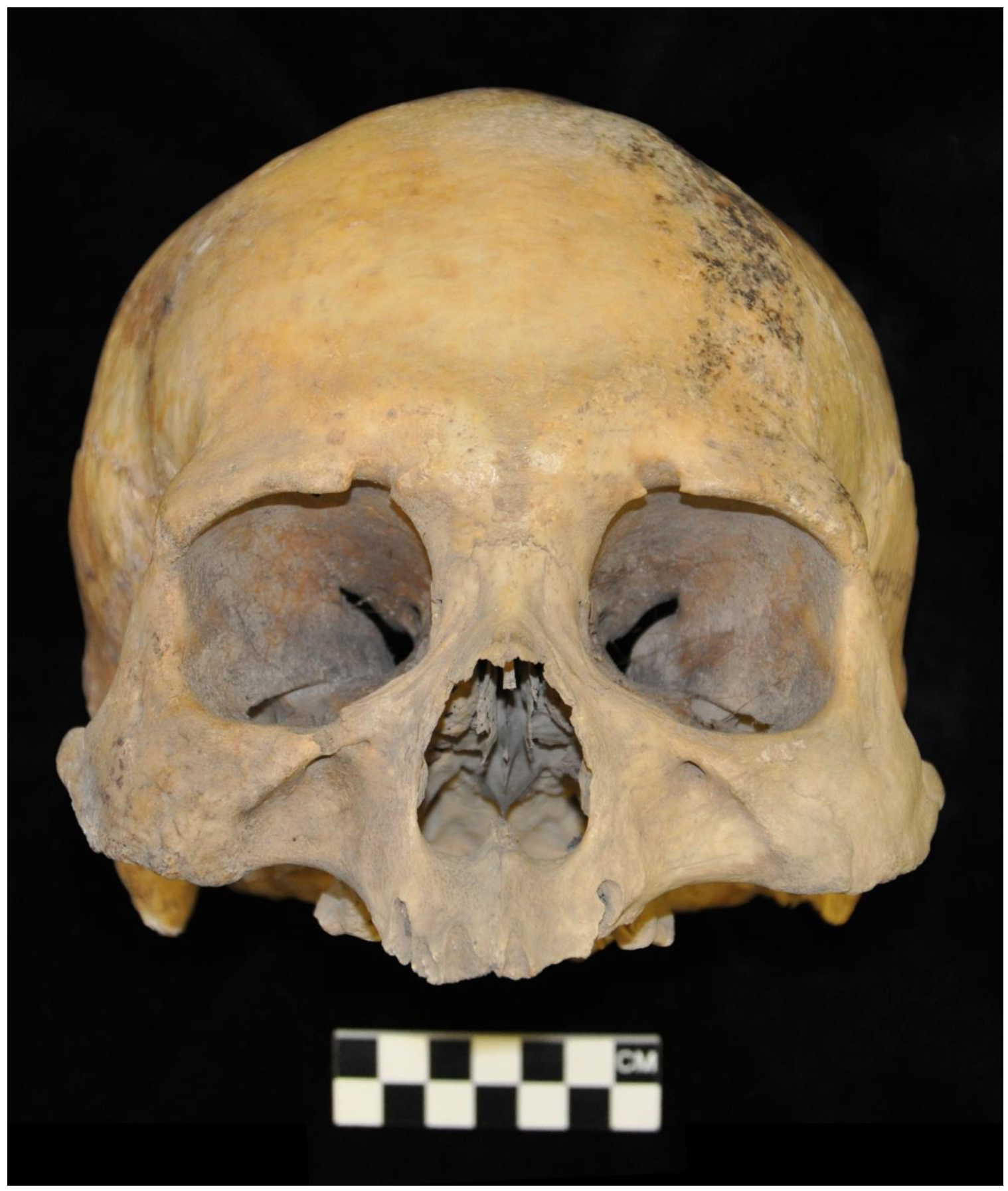

Figure 3. Anterior view of $\mathrm{C} 1$. 


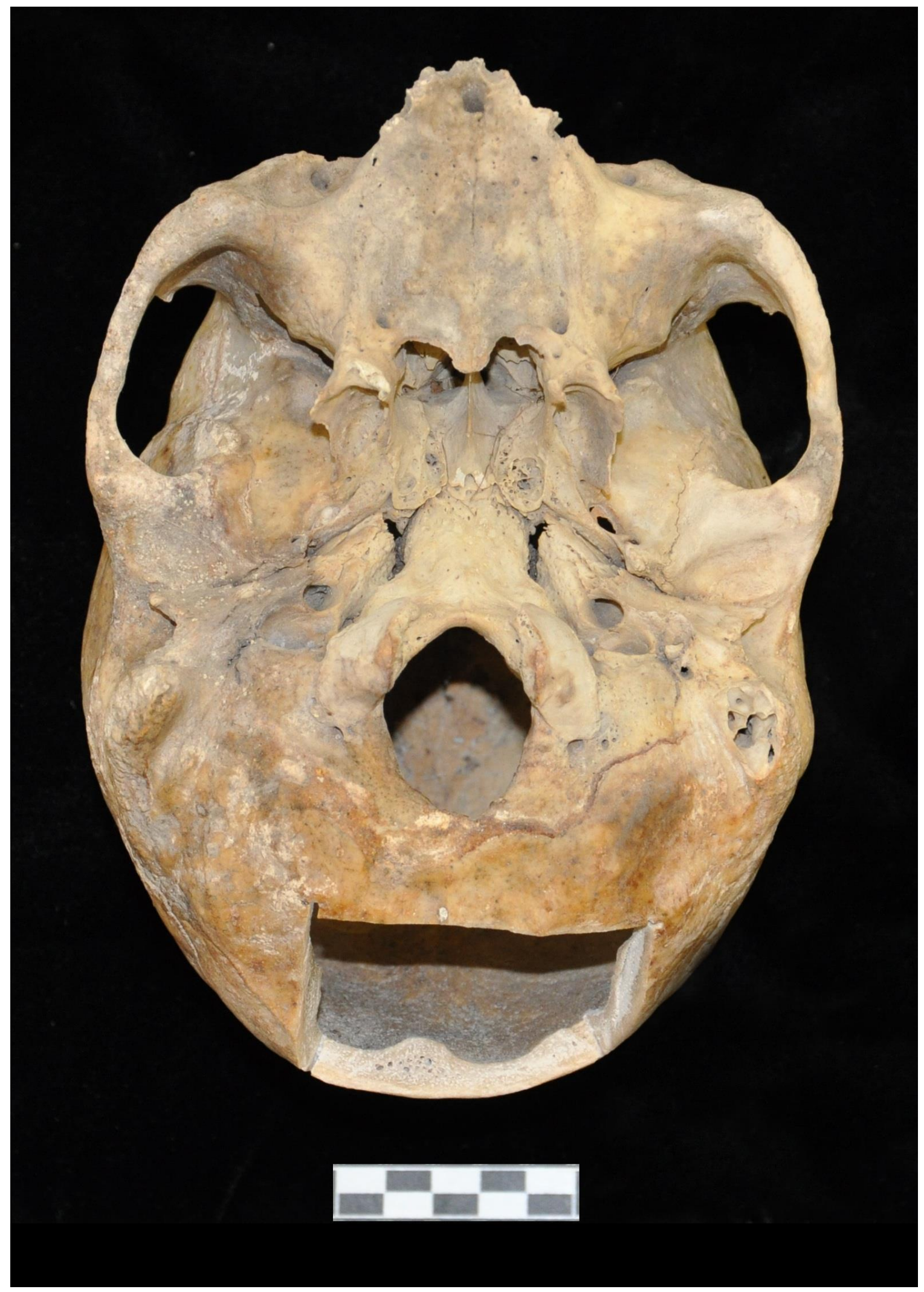

Figure 4. Inferior view of $\mathrm{C} 1$. Note the rectangular section of the occipital that was removed for radiocarbon dating. 


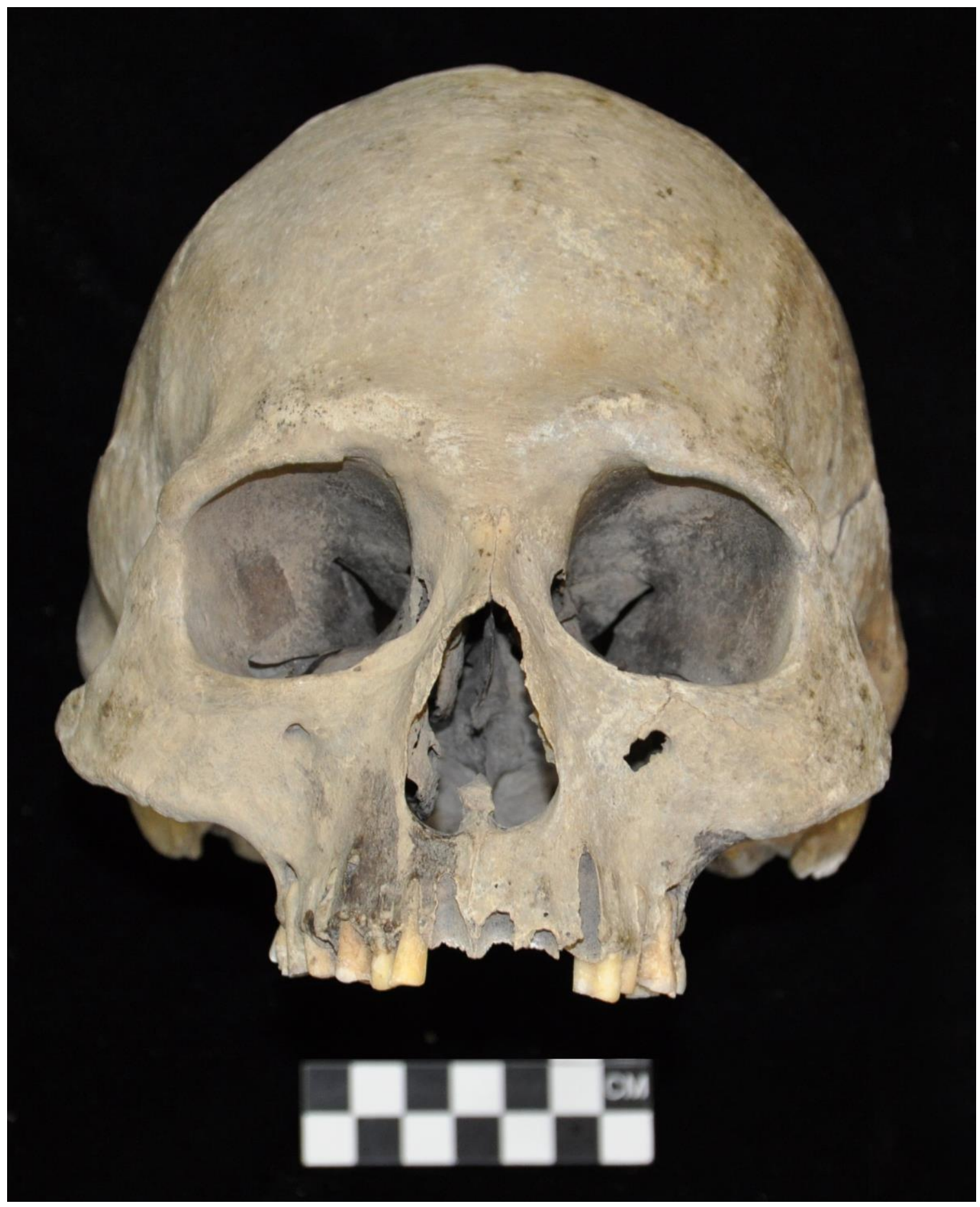

Figure 5. Anterior view of C2. 


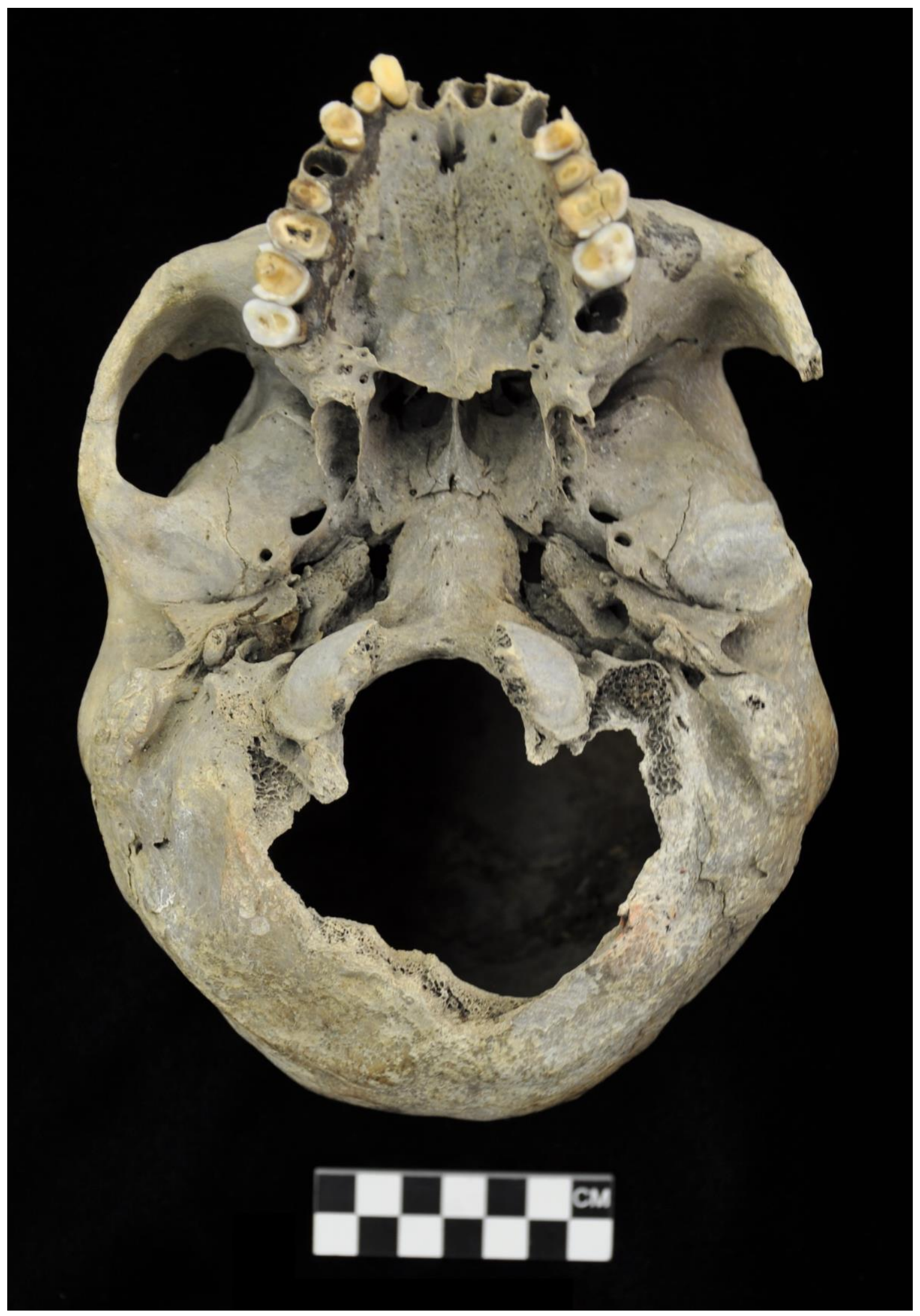

Figure 6. Inferior view of $\mathrm{C} 2$. 


\section{RADIOCARBON ASSAY AND STABLE ISOTOPIC ANALYSIS}

Samples from both crania were submitted for radiocarbon assay to determine their chronological age. The samples consisted of a rectangular section from the occipital region of specimen $\mathrm{C} 1$ and a molar from specimen C2. They were submitted to Beta Analytic for collagen extraction, AMS (accelerator mass spectrometer) dating, and isotopic measurement. The resulting radiocarbon assays (Table 1) were very similar and strongly overlap at the 2 sigma probability level.

\section{Table 1. Radiocarbon and Isotopic Data.}

\begin{tabular}{lllllll}
\hline Item & $\begin{array}{l}\text { Sample } \\
\text { Beta No. }\end{array}$ & $\begin{array}{l}\text { Measured } \\
\text { Radiocarbon } \\
\text { Age (B.P.) }\end{array}$ & $\delta 13 \mathrm{C}$ & $\delta 15 \mathrm{~N}$ & $\begin{array}{l}\text { Conventional } \\
\text { Radiocarbon } \\
\text { Age (B.P.) } \\
\text { (OxCal 4.2) }\end{array}$ & $\begin{array}{l}\text { Calibrated } \\
\text { Age Range } \\
\text { 2 sigma }\end{array}$ \\
\hline C1 & 297583 & $1170+30$ & $-16.8 \%$ & $10.2 \% 0$ & $1300+30$ & A.D. 660-770 \\
C2 & 297584 & $1150+30$ & $-17.0 \%$ & $11.1 \% 0$ & $1280+30$ & A.D. 660-775 \\
\hline
\end{tabular}

The conventional radiocarbon ages before present were calibrated using OxCal 4.2 with the following results. At the 95 percent probability level, $\mathrm{C} 1$ has an age estimate range of A.D. 660-770, while C2 has a range of A.D. 660-775. The radiocarbon ages of both crania are slightly younger but strongly statistically overlap with the radiocarbon age of the isolated burial from the nearby Carpenter Bend site, with a reported age of $1350 \pm 40$ B.P., which yields a calibrated 2 sigma range of A.D. 615-770 (Malof and Taylor 2011). In terms of the local chronological sequence, all three of these individuals date to the Terminal Archaic period, at the end of the long Archaic era during the transition from the use of atlatl to the bow and arrow as the primary weapon system. While adoption of the new weapon system is traditionally considered the hallmark of the Late Prehistoric era, Lohse et al. (2014) argue that the new era did not begin until A.D. 1300 with the return of bison to the region and the onset of the Toyah phase (or interval).

The ratios of stable isotopes of carbon $(\delta 13 \mathrm{C})$ and nitrogen $(\delta 15 \mathrm{~N})$ derived from human bone collagen reflect dietary contributions from plants and animals (Mays 2010:265-277). Katzenberg (2008) provides a useful overview of stable isotopic analysis. Of these two isotopic ratios, carbon data is available from a larger number of human burials from hunter-gatherer contexts.

The measured stable isotope values for Cranium $1(-16.8 \% \circ \delta 13 \mathrm{C}$ and $10.2 \% \circ \delta 15 \mathrm{~N})$ and Cranium $2(-$ $17.0 \%$ o $\delta 13 \mathrm{C}$ and $11.1 \% \mathrm{o} \delta 15 \mathrm{~N}$ ) are quite similar to one another, although $\mathrm{C} 2$ has a slightly more enriched nitrogen ratio. The isotopic values of the crania fall within the general range of hunter-gatherer populations, rather than sedentary populations reliant on maize, which became a dietary staple in many areas across temperate North America after A.D. 1000.

A recent in-depth study of carbon and nitrogen isotopes from various hunter-gatherer burial populations in the adjacent Gulf coastal plain of Texas suggests that the values derived for both crania are consistent with what would be expected from inland populations (Hard and Katzenberg 2011). The closest geographic comparisons are with two prehistoric cemeteries just below the Edwards Escarpment in and near San 
Antonio, Texas, some $125 \mathrm{~km}$ to the south. A sample of six individuals dating to the Late Archaic period from the Olmos Dam site have significantly lower nitrogen values ( 8.7 to $9.3 \%$ ) as well as somewhat lower carbon values (-17.3 to -19.3\%; Hard and Katzenberg 2011:Table 7b). Seventeen hunter-gatherer burials from the Coleman site also have significantly lower nitrogen values (7.6 to 10.0\%; Mauldin et al. 2013:Table 2), although the carbon ratios of both crevice crania fall within the Coleman range of carbon ratios from collagen $(-15.6$ to $-18.2 \%)$.

Turning to the Edwards Plateau, there are fewer comparative samples and only carbon isotopes are available for most. Focusing on $\delta 13 \mathrm{C}$ values, the ratios derived from both crania at $-17.0 \%$ and $-16.8 \%$ are lower than the Carpenter Bend individual (-18.3\%), the geographically closest comparison (Malof and Taylor 2011). Looking to the west, both crania ratio values fall slightly below the mean value (-17.4\%o) from seven samples representing at least five individuals from the Stiver Ranch Burial Sinkhole near Junction (Alvarez 2005) and well above the $-15.8 \%$ mean value from 16 individuals from Bering Sinkhole to the northwest of Kerrville (Bement 1994:Table 15). The $\delta 15 \mathrm{~N}$ values (10.2\%o and $11.0 \%$ ) of both crania are also well above the $8.1 \%$ mean from the Bering Sinkhole population.

In summary, while the $\delta 13 \mathrm{C}$ values from the recovered crania are within the range of prehistoric burials across and just below the Edwards Plateau, the $\delta 15 \mathrm{~N}$ values are significantly higher than the comparative sample from the greater region. This suggests that the individuals represented by these crania had a substantially different diet than would be expected from a local population. The high nitrogen values could indicate a diet heavily reliant on fish like that Hard and Katzenberg (2011) inferred from riverine populations on the Texas coastal plains.

\section{SUMMARY AND CONCLUSIONS}

Two isolated and well-preserved crania found in an unprotected limestone crevice along a creek west of Austin, Texas, are of Native American ancestry as shown by skeletal analysis. Radiocarbon dating shows they are contemporary to one another and probably date to the seventh or eighth century A.D. at the end of the Archaic era. Archeological excavations uncovered no evidence that the crania were interred in the crevice during prehistoric times. There were also clear indications that the crania had been stored and handled after original disinterment. Traces of an adhesive in the maxilla of one cranium suggested that several of the teeth had been glued in place. The other cranium had traces of handling polish on the frontal and parietal bones.

A plausible, but speculative, explanation consistent with the facts is that the crania were removed from an

unknown locality, kept in a private collection and handled for a period of time and then surreptitiously placed into the crevice to "return" the human remains to the earth. Regardless of motivation, the crevice where the crania were found in 2009 was not the original locality where the deceased were interred. This assessment is based on the lack of additional evidence of human osteological or dental material in the crevice, and the fact that the crevice is essentially open to the elements and is situated less than $1 \mathrm{~m}$ above a permanent stream prone to periodic flooding. The chance of an interment remaining intact and undisturbed in such a setting for over a thousand years is considered extremely unlikely.

Several lines of evidence also suggest that the crania are probably not from the prehistoric populations of the region. To begin with, prehistoric human remains previously found on the Edwards Plateau, such as the 
skeleton found less than $15 \mathrm{~km}$ to the north along the Colorado River (Malof and Taylor 2011), are characteristically poorly preserved relative to the condition of these crania (cf. Steele et al. 1999:144). Measured stable isotopic rations of carbon $\left({ }^{13} \mathrm{C} /{ }^{12} \mathrm{C}\right)$ and nitrogen $\left({ }^{15} \mathrm{~N} /{ }^{14} \mathrm{~N}\right)$ derived from human bone collagen samples from the two crania are not consistent with other burial populations from on and near the Edwards Plateau. The nitrogen values are higher than all other comparative samples from the region, suggesting a different diet, perhaps very high in fish.

\section{UNEXPLORED RESEARCH AVENUES}

This study shows the value and necessity of taking a multidisciplinary approach to evaluating the significance, context, and cultural affiliation of isolated human skeletal remains. While the origin and specific cultural affiliation cannot be determined from the available data, as more craniometric, isotopic, and genetic data become available from prehistoric North American populations, future studies may be more precise in identifying regional populations for isolated crania recovered from looted or disturbed contexts.

\section{ACKNOWLEDGEMENTS}

We would like to thank Meredith Tise who assisted with the initial analysis, as well as Brooke Boyer and Chris Hodges, who assisted with the fieldwork. Robert Hard kindly shared isotopic insights. Several anonymous reviewers of this paper provided very helpful suggestions.

\section{REFERENCES CITED}

Alvarez, C.

2005 Stable Carbon Isotopes from the Stiver Ranch Burial Sinkhole (41KM140). Bulletin of the Texas Archeological Society 76:165-172.

Ascadi, G. and J. Nemeskeri

1970 History of Human Life Span and Mortality. Akademiai Kiado, Budapest, Hungary.

Bement, L. C

1994 Hunter-Gatherer Mortuary Practices during the Central Texas Archaic. University of Texas Press, Austin.

Black, S. L.

1989 Central Texas Plateau Prairie. In From the Gulf to the Rio Grande: Human Adaptation in Central, South, and Lower Pecos Texas, edited by T. R. Hester, pp. 17-38. Research Series 33. Arkansas Archeological Survey, Fayetteville.

Buikstra, J. E. and D. H. Ubelaker (editors)

1994 Standards for Data Collection from Human Skeletal Remains: Proceedings of a Seminar at the Field Museum of Natural History. Research Series 44. Arkansas Archeological Survey, Fayetteville. 
Collins, M. B.

2004 Archeology in Central Texas. In The Prehistory of Texas, edited by T. K. Perttula, pp. 101-126. Texas A\&M University Press, College Station.

Field, A.

1956 Archeological Investigations in Lampasas, Burnet, Llano, and San Saba Counties. Bulletin of the Texas Archeological Society 27:161-184.

Givens, R. D.

1968 A Preliminary Report on Excavations at Hitzfelder Cave. Bulletin of the Texas Archeological Society 38:47-50.

Haglund, W. D. and M. H. Sorg (editors)

1997 Forensic Taphonomy: The Postmortem Fate of Human Remains. CRC Press, Boca Raton, Florida.

Hard, R. J. and M. A. Katzenberg

2011 A Stable Isotope Study of Hunter-Gatherer-Fisher Diet, Mobility, and Intensification on the Texas Gulf Coastal Plain. American Antiquity 76:709-751.

Katzenberg, M. A.

2008 Stable Isotope Analysis: A Tool for Studying Past Diet, Demography, and Life History. In Biological Anthropology of the Human Skeleton, edited by M. A. Katzenberg and S. R. Saunders, pp. 413-442. John Willey and Sons, Hoboken, New Jersey.

Kelley, J. C.

1941 51D3-2 Grelle Site. Unpublished MS on file, Texas Archeological Research Laboratory, University of Texas at Austin.

Lohse, J. C., B. J. Culleton, S. L. Black, and D. J. Kennett

2014 A Precise Chronology of Middle to Late Holocene Bison Exploitation in the Far Southern Great Plains. Journal of Texas Archeology and History 1:94-126.

Malof, A. F. and M. S. Taylor

2011 A Terminal Archaic Burial from the Central Colorado River Basin, Travis County, Texas. Bulletin of the Texas Archeological Society 82:251-280.

Mauldin, R. P., R. J. Hard, C. M. Munoz, J. L. Z. Rice, K. Verostick, D. R. Potter, and N. Dollar

2013 Carbon and Nitrogen Stable Isotope Analysis of Hunter-Gatherers from the Coleman site, a Late Prehistoric Cemetery in Central Texas. Journal of Archaeological Science 40:1369-1381.

Mays, S.

2010 The Archaeology of Human Bones. Routledge, New York.

Meindl, R. S. and C. O. Lovejoy

1985 Ectocranial Suture Closure: A Revised Method for the Determination of Skeletal Age at Death Based on the Lateral-Anterior Sutures. American Journal of Physical Anthropology 68:57-66.

Perttula, T. K.

2001 Hunter-Gatherer Mortuary Practices in the Rio Grande Plains and Central Coastal Plains Archeological Regions of Texas. La Tierra 28(3-4):2-83. 
Prewitt, E. R.

1985 From Circleville to Toyah: Comments on Central Texas Chronology. Bulletin of the Texas Archeological Society 54:201-238.

Russell, F. B.

1936 Archeology in Bell County. Bulletin of the Central Texas Archeological Society 2:49-51.

Steele, D. G., B. W. Olive, and K. J. Reinhard

1999 Central, South, and Lower Pecos Texas. In Bioarcheology of the South Central United States, edited by J. C. Rose, pp. 132-152. Research Series 55. Arkansas Archeological Survey, Fayetteville.

Walker, P. L.

2008 Sexing skulls using discriminant function analysis of visually assessed traits. American Journal of Physical Anthropology 136:39-50.

Watt, F. H.

1936 A Prehistoric Rockshelter Burial in Bell County, Texas. Bulletin of the Central Texas Archeological Society 2:5-27. 